\title{
A STATE SAVES A CITY: THE NEW YORK CASE
}

\author{
Donna E. Shalala* and Carol Bellamy**
}

In the Spring of 1975 the City of New York was unable to market its debt. The municipal bond and note markets had closed because of growing concern about the City's finances. More specifically, it was discovered that the country's largest city had for more than a decade been using questionable accounting and borrowing practices to eliminate its annual budget deficits.

\section{Underlying Causes of the Fiscal Crisis}

Fiscal mismanagement was the immediate but not the fundamental cause of New York's difficulties. There are four basic reasons for the condition of New York City's finances in 1975. They are:

1) changing population and economic characteristics;

2) national economic difficulties;

3) state and federal government action;

4) inaction and weaknesses in the political system itself.

1. Socio-Economic Factors. Like those of other large, older northeastern and midwestern cities, New York's population and economic activities had for almost three decades been going through a process of realignment. The population in each of these metropolitan areas had sorted itself out between central city and surrounding suburbs -middle-income people went to the suburbs, lower-income people stayed put. The middle class left in search of better schools for their children and a piece of land they could call their own. Retail trade followed its customers. Simultaneously, other kinds of economic activity began to shift away from the central cities. Heavy manufacturing went to the suburbs in search of enough land to build horizontal rather

* Associate Professor of Politics, Teachers College, Columbia University; Director and Treasurer, Municipal Assistance Corporation for the City of New York.

** Member, New York State Senate; counsel to Esanu, Katsky \& Korins, New York, N.Y.

THE FOLLOWING CITATION WILL BE USED IN THIS ARTICLE:

Municipal Assistance Corporation for the City of New York, ANNund REPORT (1976) [hereinafter cited as MAC REPORT]. 
than vertical plants. Some industries relocated to the South and West where cheap land and lower labor costs were available. ${ }^{1}$

This population and economic redistribution left New York and other big cities with heavy concentrations of poverty. In the decade between 1960 and 1970, New York City's poverty population (measured as a percentage of its total population) grew from one of the lowest in the country-well below the national average-to one which exceeded that average. ${ }^{2}$

The implications of these economic and population shifts were enormous. They led to significant reductions in private sector employment; in New York the number of private sector jobs decreased from a peak of 3.8 million in 1969 to 3.4 million by the end of 1975 , a decline of more than 11 percent. $^{3}$ Most importantly, however, the tax bases of New York and other older cities slowed their growth or actually declined at precisely the time when a needy population and an older physical plant (sanitation equipment, park facilities, etc.) required high service levels. ${ }^{4}$

2. National Economic Difficulties. The nation's economic illnesses were also in part responsible for the sharp rise $\mathrm{m}$ the cost of city services and welfare expenditures as well as the deterioration in city revenues. Large cities like New York are more vulnerable to economic downturns because, unlike other municipalities which rely primarily on property taxes for their revenue, New York relies more heavily on sales and income taxes which tend to be more susceptible to cyclical variations. ${ }^{5}$ In addition to the impact of the recession on the tax base, the effects of the national economic downturn are clearly revealed in high unemployment figures. The only up-to-date measure of central city economic activity available is the unemployment rate. One study of New York's unemployment patterns over time concluded that during the 1970s, "it is reasonable to assume that the New York

1. These trends are analyzed in detail in Blaydon \& Gilford, Financing the Cities: An Issue Agenda, 1976 Duxe L.J. 1057.

2. Staff of the Joint Econ. Comm., 94th Cong., 1st Sess., New York Crty's Financial Crisis: an Evaluation of Its Economic Impact and of Proposed Policy Solutions 15-16 (Comm. Print 1975).

3. R. Bahl \& A. Campaell, The Economic and Fiscal OUtlook for New YorK CITY 2 (March 24, 1976) (study presented to the Mediation Panel for the Negotiations between the MTA and the TWU, New York City).

4. See Blaydon \& Gilford, supra note 1, at 1079-89.

5. A. OTt \& J. Yoo, New York Citr's Financial Crisis 14 (American Enterprise Institute for Public Policy Research, Domestic Affairs Study No. 40, 1975). 
economy has been more seriously affected by the recession than the economies of most other large central cities."

However, the economic problems of New York City are not transitory; the recession intensified them, to be sure, but it provides only a partial explanation. At least one analysis of the City's economic base suggests that even a national recovery may not be a panacea. ${ }^{7}$ The impact of federal investment of tax dollars in the South and West provides another partial explanation; ${ }^{8}$ the resulting shift in the location of economic activity has left New York's economic base in deeper trouble than before. Bahl and Campbell provide additional explanations, including the high cost characteristics of the New York area. They write:

These high costs are produced by a variety of factors related to wage levels, congestion, energy costs, and higher taxes. It is also suggested by some that a lack of land availability causes companies looking to expand or to relocate, to move beyond the city limits and more and more frequently beyond the region. And to the extent that social needs of the City residents have contributed to this declining base, the situation is reinforcing since the job losses further deplete the revenues of the City while not reducing proportionately the need for public services. ${ }^{9}$

3. State and Federal Policies. The fact that the City performs so many functions is not only a matter of taste or choice. No other large city in this country has as many services assigned to it as the City of New York. In addition to normal housekeeping functions-police, fire, and sanitation-New York operates hospitals, elementary, secondary and higher education facilities, and subsidizes health care and mass transportation. ${ }^{10}$ Unlike other cities, New York must bear twenty-five percent of its welfare costs and fifty percent of the expenses of home relief prograins mandated by the state constitution. ${ }^{11}$

State government is responsible for this heavy burden of functional assignments. The conspicuous failure of state governinent either to expand the boundaries of the City to include the newly developed middle-income suburbs or to provide enough aid to offset the loss in tax revenues has contributed to the City's current crisis. There has, however, been an increase in state aid to the City. The City of New

6. New York City's Financial CRisis, supra note 2, at 21.

7. A. OTT \& J. Yoo, supra note 5, at 16.

8. The dimensions of this shift are a matter of some controversy. See Blaydon \& Gilford, supra note 1, at 1106-07.

9. R. BAHL \& A. CAMPBELL, supra note 3, at 6.

10. See MAC REPORT 7.

11. See N.Y. Soc. Serv. LAW $\$ 154$ (McKinney 1976). 
York has received an increase in total aid from the state of more than 600 percent since 1969 , compared to 300 percent for the rest of the state. However, half of this increase was for state-mandated welfare programs; when welfare aid is excluded, the City still receives less aid per person than the rest of the state of New York. ${ }^{12}$

While the City's powers and responsibilities are determined by the state, the federal government must also bear part of the blame. Federal program mandates of the 1960s fell most heavily on those local jurisdictions whose education, health and welfare programs received the most substantial federal aid. In addition, the federal government made it easier for middle and upper income families to move to suburbs by providing FHA and GI loans, and by the construction of federally financed highways. ${ }^{13}$

New York City itself probably tried to do too much for too many. It tried to use public employment programs as a vehicle for the redistribution of income. Whether it is theoretically proper for a city government to become the employer of last resort is questionable; the fact is that New York City made such a policy determination in order to fill the vacuum left by all other levels of government, especially the federal government. $^{14}$

4. Political Explanations. New York's elected officials also found it difficult to say "no." To a political scientist observing the City's government over the last decade, it seemed as if the trade-off mechanism of the political process had broken down. The City's leaders seemed to respond to most groups by saying "yes" without demanding quid pro quo. They failed to alternate or compromise the specific demands of various interests. The nature of the political process and the necessity for re-election every four years reinforced this style. The political process is characterized by incrementalism, i.e., a policy of taking small steps. Incrementalism applied to the budget means that last year's budget is the best indicator of how this year's budget should be drafted. When the new budget is put together, increases are simply tacked on to existing programs; there is no questioning of whether existing programs are still useful.

The important point is that politicians do not take bold risks. They take small steps. They simply add to what has been done previ-

12. See Shalala, State Aid to Local Government, in Governing New York State: The Rockefeller Years 100 (R. Connery \& G. Benjamin eds. 1974). Calculations are based on newer data from recent state budgets.

13. Sec Campbell \& Shalala, Problems Unsolved, Solutions Untried: The Urban Crisis, in The States and the Urban Crisis 13 (A. Campbell ed. 1970).

14. See MAC RePort 7. 
ously rather than re-analyze or reorganize what already exists. Such myopic behavior is inconsistent with long-term fiscal planning; it does not even recognize a pattern of economic decline. The nnyopia of the political hierarchy went largely unchecked during the 1960 s because of the muted role taken by some interest groups in that decade. New York's civic groups, the media and the academic commumity failed to watch the City's finances very carefully. It is in the nature of the public fimance system to frighten off all but the most stalwart; the City's outside protectors trusted the government's experts. Indeed, unlike other cities, New York had most of the skilled budget experts on its payroll. The predictable result was a dearth of discussion about a growing fiscal crisis.

\section{Deficit Planning}

When economic activity shifts away from central cities without a compensating reduction in the cities' fmancial or service responsibilities, service costs imevitably increase more rapidly than the revenue to support them. Budget deficits are thus created. To close such gaps, most older large cities liave four alternatives: 1) cutting services; 2) raising taxes; 3 ) convimcing their states, and the federal government, to give them more aid or to take over the entire cost and/or administration of particular services; or 4) undertaking governmental reorganization.

The final alternative-reorganizing the local government system by stretching the boundaries of a city to include its surrounding suburbs, thereby giving the city access to the stronger tax base of its suburbs-faces strong political obstacles. There has been one regional exception, the South, and in a few areas some single-function metropolitan or regional districts have been created. ${ }^{15}$ For most older American cities (particularly those located in the Northeast and the Midwest), every year simce the late 1950s has seen a new budget deficit that had to be closed by either raising taxes, increased intergovernmental aid, or introducing service cuts. The single exception was the City of New York, which found other sources of money.

\section{Borrowing-A New Current Revenue}

New Yorkers have, of course, felt the sting of increased taxes, the relief of increased state and federal aid, and some decrease in services. But the City also used various borrowing and accounting techniques to

15. See Blaydon \& Gilford, supra note 1, at 1091-92. 
finance its annual budget deficits. Many of these were authorized by the state legislature, and depended on the "peculiarities and permissiveness of the City's accounting procedures"; their use assumed that the "growing City debt was marketable in ever increasing volume."16 The City underestimated expenses and overestimated revenues through an accounting system that often treated expenses on a cash basis and revenues on an accrual basis. It used the capital budget to finance expense items, and used an out-of-date actuarial base for municipal employee pension fund contributions which understated the true cost of the pensions. But the principal technique einployed by the City was the use of short-term borrowing to finance current operating expenses. $^{17}$

It was the misuse of borrowing that distinguished New York froin the other cities and was the fundamental cause of the City's most recent crisis. Borrowing is not new to local governments. Every local government does it, for two purposes: long-term financing and cash flow. Long-term borrowing is capital borrowing-bonding. ${ }^{18}$ The second kind of borrowing, done for cash-flow purposes, is short-term or seasonal borrowing-issuing notes. ${ }^{19}$ Two short-term borrowing techniques were used by the City of New York for its expense budget. The first was the utilization of tax anticipation notes (TANS), which were issued in anticipation of property taxes. The second was the issuance of revenue anticipation notes (RANS) sold in anticipation of all other sources of revenue.

The immediate cause of New York City's 1975 fiscal crisis was its misuse of both bonds and notes. Basically, the City used long- and short-term borrowing to erase its annual budget shortfall. It borrowed in increased amounts against accrued (but in fact uncollectable) tax revenues, and shifted payment dates for payrolls and other expenses forward to future fiscal years. In addition, the City used long-term debt to finance such non-capital programs as manpower training and

16. MAC REPORT 7.

17. See id.

18. "Bonds are long-term obligations, maturing in not less than one year. Sold primarily to finance long-term capital investments, bonds have traditionally comprised the bulk of state and local government financing, although this pattern has altered over the past decade." Forbes \& Petersen, Background Paper to BuILding a Broader Market: Report of the TWentieth Century Fund Task Force on the Municipal BoNd MaRKET 38 (1976).

19. "Notes are short-term obligations with a maximum maturity of one year or less. Notes are customarily used to smooth out the differences in cash flow between revenues and expenditures, to meet unexpected deficits, or to provide interim financing of projects in anticipation of later bond sales." Id. 
vocational education and to pay an increasing array of other recurring expenses, thereby shifting many expense items to its capital budget. Thus the City was able to present the appearance of having balanced its budget. ${ }^{20}$ In fact, such actions were effectively creating permanent additions to the City's outstanding debt. Once it became ensnarled in this labyrinthine system, the City had to continue to borrow in order to pay off previous debts and to finance new deficits. ${ }^{21}$

One other complex fiscal inaneuver added to the City's borrowing needs: the use of bond anticipation notes (BANS). While it waited for an unpredictable market to offer lower interest rates on long-term bonds to finance its iniddle-income housing program, the City issued relatively low interest notes. The projects were built, but the market never went down so that bonds could be floated. In an effort to ininiinize interest costs passed through to housing companies and tenants, the City never converted the notes issued for subsidized housing (Mitchell-Laina) to long-term bonds or federally insured mortgages. Instead, it continued to "roll over," or refinance, the short-term debt issued for that purpose. ${ }^{22}$

With the discovery of these borrowing techniques the City had found an apparently inexhaustible source of revenue, one that did not require begging at the doors of other unfriendly governments (state and/or federal) or generating the ire of local citizens by tax mcreases or spending cuts. It was a seemingly "perfect revenue." Indeed, by

20. See MAC Report 7; A. OTr \& J. Yoo, supra note 5, at 2-7.

21. The following table, reprinted from MAC REPORT, at 8 , illustrates the quantity and types of borrowing undertaken by the City in the five years immediately preceding its fiscal crisis:

New York City Balance Sheet Items

(Fiscal Years Ending June 30)

(\$ Millions)

Short-term Debt

Budget Notes

Tax Anticipation Notes

Revenue Anticipation Notes

Bond Anticipation Notes

(Including Notes for

Limited Profit Housing)

Urban Renewal Notes

Total Short-term

Long-term Debt

(Net of Sinking Fund Assets)

Grand Total

\begin{tabular}{llllllll}
1970 & 1971 & 1972 & 1973 & 1974 & 1975 & $1970-75$ \\
\hline
\end{tabular}

$\begin{array}{rrrrrrr} & 308 & 461 & 308 & 308 & \overline{380} & +210 \\ 170 & 206 & 232 & 265 & 317 & 2,560 & +2,023\end{array}$

\begin{tabular}{rrrrrrr}
468 & 587 & 688 & 957 & 909 & $1,570+1,103$ \\
55 & 94 & 86 & 94 & 84 & 30 & \pm 25 \\
1,229 & 2,291 & 2,647 & 2,511 & $\underline{3,416}$ & 4,540 & $+3,311$ \\
\hline
\end{tabular}

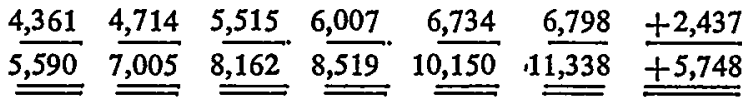

22. See id. at 7; A. Orr \& J. Yoo, supra note 5, at 6. 
the beginning of fiscal year 1976 the City expected to borrow over nine billion dollars:

a) almost $\$ 2$ billion in the bond market to cover its capital facilities commitınents, along with more than $\$ 700$ inillion to support operating expenses;

b) funds to refinance or "roll over" $\$ 1.2$ billion in MitchellLama bond anticipation notes (BANS);

c) $\$ 1.5$ billion in notes for norinal cash flow and seasonal borrowing purposes;

d) $\$ 3$ billion in notes to refinance the notes issued to cover the deficit accumulated over the decade;

e) $\$ 1$ billion in new notes to finance the 1976 fiscal year deficit.

If the City had been able to borrow these amounts, it would have issued over $\$ 500$ million in notes per month and nore than $\$ 500$ million in bonds per quarter. ${ }^{23}$

\section{Changes in the Market for Municipal Debt}

The effective closing of the mumicipal debt inarket because of the discovery that the City had misused its borrowing power unfortunately coincided with other inarket changes. A number of factors, including the recession, inade 1975 a highly competitive year for mumcipal bonds. Short-term borrowing had quadrupled in eight years while long-term debt had doubled. ${ }^{24}$ This meant that New York had nore competition from other inunicipalities than ever before. Just as important, bond customers had changed drainatically durimg this period. A recent congressional study reported that since 1970 there has been a decline in the proportion of the market represented by the commer-

23. See New York City's Fiscal Problem: Its ORIGins, Potential Repercussions, and Some Alternative Policy Responses (Congressional Budget Office Background Paper No. 1, 1975) reprinted in Congressional Budget Office Oversight, Hearings Before the House Comm. on the Budget, 94th Cong., 2d Sess., Part 2, at 50-51 (1976).

24. See id. at 54 (Tables 1 \& 2):

VOLUME OF IMUNICIPAL BORROWING

(Amounts are par values in millions of dollars)

\begin{tabular}{cccc}
\hline Year & Long-term & Short-term & Total \\
\hline 1967 & 14,300 & 8,000 & 22,300 \\
1968 & 16,300 & 8,600 & 24,900 \\
1969 & 11,700 & 11,700 & 23,400 \\
1970 & 18,888 & 17,811 & 35,999 \\
1971 & 25,006 & 26,259 & 51,265 \\
1972 & 23,748 & 24,705 & 49,018 \\
1973 & 23,957 & 24,705 & 48,662 \\
1974 & 24,317 & 29,543 & 53,860 \\
$1975 *$ & 30,124 & 33,932 & 64,056
\end{tabular}

* Annual rate based on January-June volume. 
cial banks. ${ }^{25}$ This was a particular problem for the short-term market, in which the large commercial banks played a major role. There were many reasons for their reduced interest in bonds. A major factor was their diminished need for tax-exempt bonds because of setbacks they had suffered in their real estate ventures. Indeed, the need for greater liquidity in their portfolios was forcing them to diversify their holdings.

\section{The Solutions}

Faced with imminent default on its debt, the City turned to the state for assistance. The state had legal responsibility for all local jurisdictions; their powers, after all, were totally derived from the state. ${ }^{20}$ New York State's options were limited by legal, political and time constraints. Neither formal bankruptcy nor default was seriously considered as an alternative by policymakers in early 1975 . Instead, the state reviewed four approaches: 1 ) increasing aid; 2) directly assuining the cost of selected city services; 3) increasing taxes; 4) resorting to borrowing itself to cover the City's bad debts.

\section{The Creation of " $M A C$ "}

Despite the absence of any existing New York legislation to deal with this financial emergency, the state assumed a significant measure of responsibility. First, the City was advanced $\$ 800$ million in state aid. Second, on June 10,1975, the legislature established the Municipal Assistance Corporation for the City of New York (MAC). ${ }^{27}$ MAC,

\begin{tabular}{|c|c|c|c|c|c|c|c|}
\hline \multirow{4}{*}{$\begin{array}{l}\text { ANNUAL NET } \\
\text { Holder }\end{array}$} & \multicolumn{7}{|c|}{$\begin{array}{l}\text { CHANGES IN HOLDINGS OF MUNICIPAL } \\
\text { MAJOR HOLDER GROUPS (1970-1975) }\end{array}$} \\
\hline & \multirow{3}{*}{$\underset{1970}{\text { (Amount }}$} & \multirow{3}{*}{$\begin{array}{l}\text { re par } \\
1971\end{array}$} & \multirow{3}{*}{$\begin{array}{l}\text { lues in } \\
1972\end{array}$} & \multirow{3}{*}{$\begin{array}{r}\text { Inons } \\
1973\end{array}$} & \multirow{3}{*}{$\begin{array}{l}\text { dollars) } \\
1974\end{array}$} & \multirow{2}{*}{\multicolumn{2}{|c|}{$1975^{*}$}} \\
\hline & & & & & & & \\
\hline & & & & & & $\begin{array}{l}\text { First } \\
\text { Quarter }\end{array}$ & $\begin{array}{l}\text { Second } \\
\text { Quarter }\end{array}$ \\
\hline $\begin{array}{l}\text { Commercial banks } \\
\text { Households } \\
\text { All other** }\end{array}$ & $\begin{array}{r}10.7 \\
-.8 \\
1.3\end{array}$ & $\begin{array}{r}12.6 \\
-.2\end{array}$ & $\begin{array}{l}7.2 \\
1.0 \\
6.2\end{array}$ & $\begin{array}{l}5.7 \\
4.3 \\
3.7\end{array}$ & $\begin{array}{r}5.5 \\
10.0 \\
1.9\end{array}$ & $\begin{array}{r}-2.7 \\
13.9 \\
2.9\end{array}$ & $\begin{array}{l}6.9 \\
9.3 \\
4.5\end{array}$ \\
\hline Total & 11.2 & 17.6 & 14.4 & 13.7 & 17.4 & 14.0 & 20.7 \\
\hline
\end{tabular}

* Annual rate.

** This includes corporate business, state and local general funds, mutual savings banks, insurance companies, state and local government retirement funds, and brokers and dealers.

25. Id.

26. For a general discussion of the City-state relationship, see Macchiarola, The State and the City, in Governing New York State: The Rockefeller Years (R. Connery \& G. Benjamin eds. 1974).

27. N.Y. PUB. Autr. Law $\S \S 3030-40$ (McKinney 1970-75 Cum. Supp.). The history and function of MAC are reviewed in detail in MAC REPORT 11-19. 
a public benefit corporation, was to serve as an interim borrowing agency for the City. Its major responsibility was to transform the City's short-term debt into long-term obligations. Specifically, MAC was authorized to borrow $\$ 3$ billion by issuing long-term obligations to refund the City's maturing short-term debt and to pay some of the City's operating expenses. MAC bonds were backed by a four percent state sales tax levied only in the City, and the stock transfer tax. In the past, both of these taxes had been levied by or paid to the City. The MAC legislation also required the City to institute certain accounting reforms and set limits on the amount of short-term indebtedness the City could incur.

MAC is administered by a nine-member Board of Directors. All the directors are appointed by the Governor with the advice and consent of the State Senate; four directors are appointed upon written recommendation of the Mayor. The MAC legislation also provides for the appointment of non-voting representatives to the Board by the State Comptroller and certain state and city officials and legislators.

Since City securities were unmarketable, it was hoped that MAC bonds would be viewed as sufficiently stronger and different to attract potential buyers. Three factors reinforced this hope: 1) MAC bonds were being issued by a state agency and carried with them the "inoral obligation" of the state to meet any shortfall in debt service; 2) the sales and transfer tax revenues were to be diverted directly to MAC to cover its debt service costs; 3 ) the City was fimally beginning to reform itself, and MAC was specifically charged with monitoring efforts to change the City's accounting system. In spite of these assurances, as well as initial nine and one-half and subsequent eleven percent interest rates, by August of $1975 \mathrm{MAC}$ was also unable to market its bonds publicly. Faced again with the prospect of the City's default and an investment community reluctant to buy any other New York securities, the Governor instructed MAC to draft a rescue program. ${ }^{28}$

That program, enacted in the fall of 1975 during two special sessions of the legislature, had two dimensions-governmental and fiscal. The governance plan eliminated the last vestiges of fiscal home rule from the City. It placed in the hands of elected and appointed state officials the fiscal management of the City of New York. The New York State Financial Emergency Act for the City of New York ${ }^{29}$ established the Emergency Fimancial Control Board (Control Board) to

28. See MAC REPORT 11.

29. N.Y. Laws 1975 , ch. 868-70 (McKinney). 
review and supervise the financial management of the City and to control the disbursement of City monies. The legislation provided for the appointment of a Special Deputy State Comptroller to assist the new Control Board in carrying out its responsibilities. A Financial Plan of the City's projected revenues and expenditures for the fiscal years ending on June 30,1976, 1977 and 1978 was also required. The intent of the Financial Plan is to bring the City's expense budget into balance by June 30, 1978 .

A key element of the legislation is the Control Board. Statedominated, it is composed of the Governor, the Mayor, City and State Comptrollers, and three appointees of the Governor. Its functions and powers, in addition to approving the three-year Financial Plan, are significant. They mclude the power to estimate revenues and expenditures, to approve major contracts and all borrowing, to extend (if necessary) the freeze on the number of City employees through fiscal year 1978, and to disburse City revenues only after it is satisfied that the expenditures are consistent with the Financial Plan. The powers of the Control Board also extend to the so-called Covered Organizationsthe City's semi-independent agencies which provide elementary and secondary education, higher education, hospitals and other services. One significant power was intentionally left to the Mayor-the authority to determine spending priorities within the overall revenue limits imposed by the Control Board. ${ }^{30}$ The existence of the Control Board terminates six months after it finds that the City's Expense Budget has been in balance for one fiscal year in accordance with the principles of a Uniform System of Accounts.

In November of 1975 the second phase of the rescue program was enacted by the state legislature and Congress. At the state level, a financing plan was developed which included increased City taxes ${ }^{31}$ and a $\$ 2.5$ billion commitment from the five City pension funds to buy MAC or City obligations. ${ }^{32}$ There were other, sinaller commitments froin the four City sinking funds and several major banks. The most controversial part of the plan-the New York City Emergency Moratoriuun $\mathrm{Act}^{33}$-was enacted by the state legislature on November 15, 1975. In the legislative findings accompanying the Moratorium Act, the legislature concluded that there was

imminent danger that the city of New York will be unable to pay its outstanding short-term indebtedness and even to provide those basic ser-

30. Id. ch. $868, \S 4$.

31. Id. ch. 881 et seq.

32. See MAC REPORT 15.

33. N.Y. Laws 1975, ch. 874 (McKinney), as amended by id. ch. 875 . 
vices essential to the health, safety and welfare of its inhabitants and the continuation of orderly government in the city. The legislature recognizes and insists that the pledge of the "faith and credit" of the city to the payment of its obligations must be respected. The legislature further recognizes that in the current financial crisis, this pledge can be honored only if the viability and resources of the city are preserved and that the continuation of essential services is vital to such preservation. The preservation of the city, the honoring of its obligations and restoration of public confidence in the agencies of the state and of the state itself are all matters of imperative state concern and require the extraordinary exercise of the state's essential reserve and emergency powers set out in the Act to protect the vital interests of the people by sustaining the public credit and maintaining local government. ${ }^{34}$

The Moratorium Act provides that during the "moratorium period" the enforcement of short-term obligations of the City outstanding on November 15, 1975, is suspended, notwithstanding the stated maturity of such obligations. After the stated maturity, such obligations will bear interest at a rate of not less than six percent a year. The moraturium only bars actions by noteholders who have been given an opportunity to exchange their notes for longer-term MAC bonds, and have declined to do so. The Moratorium Act does not apply to City bonds. The moratorium period expires on November 15, 1978, three years from the effective date of the Act, but it may be shortened by the legislature or extended by amendment to the Moratorium Act itself. At the time it enacted the Moratorium Act, the legislature also increased the authorized borrowing capacity of MAC to $\$ 5$ billion, and made state per capita aid payments available to the City for the payment of MAC bonds. ${ }^{35}$ Since that time, MAC has made two exchange offers to holders of certain City obligations. ${ }^{36}$

\section{Id.}

35. N.Y. PUb. AUth. Law §§ 3033, 3036-a (McKinney Supp. 1976).

36. In late 1975 , legal actions were commenced contesting the validity of the Moratorium Act under the United States and New York Constitutions. On November 19, 1976, the New York Court of Appeals declared the year-old moratorium unconstitutional, reversing two lower court decisions. Flushing Nat'l Bank v. Municipal Assistance Corp., 40 N.Y.2d 731, 358 N.E.2d 848, 390 N.Y.S.2d 22 (1976). The court based its decision upon article VIII, $\S 2$ of the New York Constitution, which forbids a city from issuing debt securities unless it has "pledged its faith and credit for payment of the principal thereof and the interest thereon." Id. at 734, 358 N.E.2d at 851,390 N.Y.S.2d at 25 . Reasoning from the meaning of the words "full faith and credit" and the constitutional provisions allowing municipalities to exceed maximum tax rates to provide debt service, Chief Judge Breitel found a "constitutional imperative" that "debt obligations . . . be paid, even if tax limits be exceeded." Id. at 737, 358 N.E.2d at 852,390 N.Y.S.2d at 27 . The court rejected the assertion that the "emergency" status of the City might mandate a different holding on the binding nature of the "full faith and credit" pledge:

Emergencies and the police power, although they may modify their ap- 
The final piece of the financing plan was put in place on Deceinber 15, 1975, when the President of the United States signed the New York City Seasonal Financing Act. ${ }^{37}$ This legislation provided funds so that the City could meet its seasonal financial needs, which vary because of differences in timing between the payment of expenditures and the receipt of revenues. To implenient the Seasonal Financing Act, the City, the State, the Control Board and the United States entered into a Credit Agreement, dated Decenrber 30, 1975, pursuant to which the Secretary of the Treasury is authorized to niake short-tern loans to the City. ${ }^{38}$ The principal ainount of all such loans outstanding at any one time cannot exceed $\$ 2.3$ billion. Among the conditions that must be satisfied before any seasonal loans nray be niade is a deternination by the Secretary that there is a reasonable prospect of repayinent in accordance with the terms of the loan.

\section{Default Legislation}

Concerned about the dearth of federal legislative provisions for mumicipal default, the New York State legislature also adopted certain amendments to the Local Finance Law, applicable to the City during its emergency period..$^{39}$ Under the new law, a defaulting nunicipality or, if it refuses, its emergency financial control board, may file a voluntary petition in the state supreme court. The petition must state that the inumicipality is unable to meet its debts as they coine due, and that the municipality or its control board intends to file a repayment

plications, do not suspend constitutional principles. It is not merely a matter of application to interpret the words of the Constitution and obligations issued subject to the Constitution to mean exactly the opposite of what they say. The notes in suit provided that the city pledged its full faith and credit to pay the notes and to pay them punctually when due. The clause and the constitutional mandate have no office except when their enforcement is inconvenient. Id. at 740-41, 358 N.E.2d at 855,390 N.Y.S.2d at 29.

Despite its treatment of the merits, the court ruled that the holders of City's notes were not entitled to any immediate payments if such a remedy would be "unnecessarily disruptive of the city's delicate financial and economic balance." Id. at 741, 358 N.E.2d at 855,390 N.Y.S.2d at 29. Government, business and union leaders were thus thrust together again to devise a new refinancing plan.

On February 8,1977, the Court of Appeals ordered the City to pay the claims of the Flushing plaintiffs on a six-month timetable. The court remanded the case to a specially appointed justice of the state Supreme Court, who is to "preside over all aspects of [the] matter." The presiding justice is to oversee the payment of claims under a plan which divides creditors into three classes and gives private note-holders preference over corporations and institutions. New York City Given 6-Month Schedule by State Court to Pay $\$ 1$ Billion of Notes, Wall St. J., Feb. 9, 1977, at 33, cols. 1-2.

37. 31 U.S.C.A. $\$ 1501-10$ (1976).

38. The principal provisions of the Credit Agreement are summarized in Oversight on the New York City Seasonal Financing Act, Hearings Before the Senate Comm. on Banking, Housing \& Urban Affairs, 94th Cong., 2d Sess. 12-13 (1976) (statement of Treasury Secretary Simon).

39. N.Y. Local FIN. Law $\$ 85.00-.90$ (McKinney Supp. 1976). 
plan with the court detailing the nature and amount of the obligations which may be affected and, insofar as is practicable, the names and addresses of creditors who may be affected by the plan. The filing of the petition automatically prohibits for ninety days the doing of any act, and stays any pending action, "seeking to apply or enforce against the mumicipality . . . any order, judgment, lien, set-off or counterclaim ...."."40

The Act further provides that, upon the filing of such a petition, a Repayment Plan may be filed by the municipality or, in the event the mumicipality refuses to file such a Plan, by its control board. Upon the filing of the Repayment Plan, the court is to enter an order approving the Repayment Plan with respect to those creditors who accept the Plan or any benefits thereunder, if the court finds generally that the plan (i) provides for eventual satisfaction of City obligations; (ii) gives equitable and prompt paynuent; (iii) preserves priorities among creditors; and (iv) was approved by the Control Board. ${ }^{41}$ With the court's approval, the Plan may be inodified by the inunicipality or its control board, if circumstances warrant such a inodification. ${ }^{42}$

\section{Conclusion}

What is remarkable about New York State's actions during New York City's 1975 fiscal crisis is how easily traditional constraints to governinental action were overcome. First, fiscal home rule, long the battle cry of every big-city nıayor, was given up with barely a whimper from the City of New York. Second, through action at the state level, the incremental political process which was in part responsible for the accuinulated deficit was successfully abandoned to solve the crisis. The steps which were taken-particularly the Financial Ennergency Act and the inoratoriuin legislation-were not incremental; they were bold, innovative legislation. Third, there were serious efforts to preserve the democratic process. The Control Board legislation was carefully worded to leave spending priorities in the hands of the City's elected officials. Bankruptcy was avoided in part because of the strong belief that elected and not appointed officials ought to put the City's fiscal matters in order.

40. Id. $\S 85.30$.

41. Id. $\$ 85.40$.

42. Id. $\S 85.60$. New York state's default legislation resembles in many respects the new federal provisions for municipal insolvency, which went into effect on April 9, 1976. Act to Amend Chapter IX of the Bankruptcy Act, Pub. L. No. 94-260, 90 Stat. 315 et seq., amending 11 U.S.C. $\S \S 401$ et seq. (1970). For an exposition of the federal act, see King, Municipal Insolvency: The New Chapter $I X$ of the Bankruptcy Act, 1976 DUKE L.J. 1157. 